DOI 10.15593/2409-5125/2016.01.04

УДК 504.4.054.001.5

\author{
Е.А. Тарановская, Н.А. Собгайда, \\ Д.Ю. Маркина, П.А. Морев
}

Энгельсский технологический институт (филиал)

Саратовского государственного технического университета

имени Ю.А. Гагарина

\title{
ТЕХНОЛОГИЯ ПОЛУЧЕНИЯ И ИСПОЛЬЗОВАНИЯ КОМПОЗИЦИОННЫХ МАТЕРИАЛОВ ИЗ ХИТОЗАНА И ШЕЛУХИ ПРОСА ДЛЯ ОЧИСТКИ СТОКОВ ОТ ИОНОВ ТЯЖЕЛЫХ МЕТАЛЛОВ
}

\begin{abstract}
Описаны основные области применения биополимера - хитозана. Отмечены наиболее важные из них: медицина - в качестве средства борьбы с ожирением, связывания и выведения из организма холестерина, профилактики и лечения сердечнососудистых заболеваний, лечения злокачественных опухолей и язвы желудка и др.; пищевая промышленность - в качестве загустителя и структуры образования для продуктов диетического питания. В последнее время много работ посвящено применению хитозана для очистки стоков. Известно, что он обладает флокуляционными и сорбционными свойствами. Хитозан обладает высокой себестоимостью, поэтому в статье предложено создавать композиционные материалы на основе хитозана, которые позволят снизить себестоимость и улучшить сорбционные свойства. В качестве наполнителя предложено использовать термообработанную шелуху проса, которая обладает высокими сорбционными свойствами и является отходами переработки сельскохозяйственной продукции. Разработана технология получения и использования композиционных материалов из шелухи проса и хитозана для очистки стоков от ионов тяжелых металлов $\left(\mathrm{Pb}^{2+}, \mathrm{Cd}^{2+}, \mathrm{Zn}^{2+}\right)$. Рассчитана эффективность очистки стоков с применением исходного хитозана и композиционных гранулированных материалов на основе хитозана и термообработанной шелухи проса. Показано, что композиционные материалы на основе хитозана и термообработанной шелухи проса обладают более высокой эффективностью очистки по сравнению с исходным хитозаном. Проведены микроструктурные исследования и сняты ИК-спектры полученных материалов. Рассчитаны экономические показатели получения композиционных материалов.
\end{abstract}

Ключевые слова: хитозан, ионы тяжелых металлов, шелуха проса, сточные воды. 
Очистка сточных вод и утилизация отходов являются актуальными экологическими проблемами не только в Российской Федерации, но и в мире. Основными загрязнителями сточных вод (CВ) промышленности являются ионы тяжелых металлов (ИТМ). Тяжелые металлы (медь, цинк, свинец, кадмий и др.) представляют серьезную опасность с точки зрения их биологической активности и токсических свойств. Для минимизации воздействия на водные объекты химической отрасли на российском и зарубежном рынках имеется большое разнообразие сорбционных материалов для очистки сточных вод от ионов тяжелых металлов и нефтепродуктов. Сорбенты создаются на основе активированных углей, природных материалов, наноматериалов и др. Многие из них являются достаточно эффективными и обладают высокой сорбционной емкостью, однако зачастую энергетические и материальные затраты на их производство определяют высокую стоимость продукта, что не удовлетворяет требованиям потребителей. Вместе с тем перспективные и экономически выгодные сорбенты можно изготавливать из вторичного сырья. Данные материалы позволяют решить сразу две проблемы: очистка воды и одновременно утилизация отходов. Однако применение исходных материалов в качестве сорбентов малоэффективно, поэтому работы, направленные на создание новых дешевых и высокосорбционных материалов, полученных при активации отходов, весьма актуальны и имеют большое научное и практическое значение.

В последнее время большое внимание уделяется биологическому полимеру - хитозану. Еще в начале XIX в. французские ученые отделили хитин от ацила и получили в чистом виде новое вещество - хитозан. С тех пор было проведено множество фундаментальных исследований. Хитозану были посвящены работы трех нобелевских лауреатов (1903, 1929 и 1939 гг.). В наше время интерес к этому природному полимеру не ослабевает: о нем постоянно пишут в научных журналах, его активно обсуждают на конференциях и симпозиумах. Уникальные свойства хитина и хитозана привлекают внимание большого числа специалистов самых разных специальностей [1-3]. В настоящее время известно множество различных направлений использования хитина и хитозана, основными из которых во всем мире признаны: медицина, 
где хитозан используется в качестве средства борьбы с ожирением; связывания и выведения из организма холестерина, профилактики и лечения сердечно-сосудистых заболеваний, производства хирургических нитей, искусственной кожи, лекарственных форм антисклеротического, антикоагулянтного и антиартрозного действия, диагностики и лечения злокачественных опухолей и язвы желудка; пищевая промышленность, где хитозан применяется как загуститель и структура образования для продуктов диетического питания. Также к неоспоримым достоинствам хитозана относится его совершенная безопасность для человека и окружающей среды. В природных условиях он распадается полностью. Экологически чист [4-6].

Очистка вод успешно решена путем применения материалов на основе хитозана, имеющего высокие сорбционные и коагуляционные свойства. Известно, что хитозан может применяться как флокулянт при осаждении белков, что дает возможность его использования для очистки воды в производственном процессе. Являясь слабым катионным флокулянтом, хитозан имеет повышенную эффективность осаждения белка по сравнению с классическими методами. Продукт очистки вод может использоваться в качестве органического удобрения в сельском хозяйстве [7].

Применение хитозана для очистки сточных вод было исследовано английскими учеными, которые выявили возможность очистки от нефтепродуктов и тяжелых металлов и увеличения скорости отстаивания взвешенных частиц [8].

Использование чистого хитозана экономически не выгодно, так как средняя стоимость 1 кг хитозана составляет около 2000 руб., что превышает стоимость традиционных сорбентов (стоимость активированных углей от 80 руб. за 1 кг). Поэтому нами была разработана технология получения и использования композиционных сорбентов на основе хитона и отходов сельхозпереработки.

Цель данной работы: разработка технологии получения гранулированных материалов на основе хитозана и термообработанной шелухи проса для очистки вод от ионов тяжелых металлов. 
Хитозан, полученный по технологии $[9,10]$, представляет собой смесь полидисперсных хлопьев молочного цвета и имеет следующие характеристики: насыпная плотность 0,2738; влажность $13,8 \%$; средневязкая молекулярная масса $M^{25}=420$ кДа (килодальтон); степень дисацетилирования СД - 80 \% .

Для увеличения объемов, сорбционной емкости и снижения себестоимости хитозана нами предлагается модифицировать его термообработанной шелухой проса (ШП). Саратовская область является аграрным регионом, и данные отходы есть в изобилии. Для их хранения требуются огромные площади земель. Поэтому комбинирование хитозана шелухой проса весьма рационально и экономически целесообразно. Авторами работ $[12,13]$ подробно описаны сорбционные свойства термообработанной шелухи проса, при температуре $300{ }^{\circ} \mathrm{C}$ в течение 20 мин. При данной термической обработке, за счет выгорания происходит образование пористой структуры с размерами пор от $\approx 0,8$ до $\approx 4-5$ нм. Полученный сорбент обладает достаточно высокими сорбционными свойствами: $A_{\text {итм }} \approx$ $\approx 17 \mathrm{мг} / г$, удельная поверхность $S_{\text {уд }}=188 \mathrm{~m}^{2} / г$, суммарный объем пор по воде $V_{\text {пор }}=0,3 \mathrm{~cm}^{3} / \Gamma$ (рис. 1$)$.

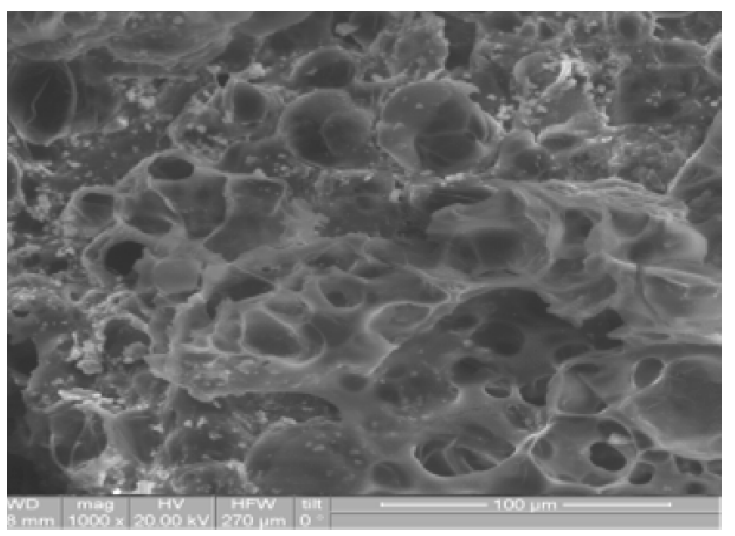

Рис. 1. Микрофотография поверхности ШП (×500)

Гранулы для очистки стоков получали двух видов:

1. Гранулы из хитозана (ГХ). Для этого изначально готовят раствор хитозана (2\%) с уксусной кислотой: к 980 мл $3 \%$-й уксусной кислоты при постоянном перемешивании постепенно в течение 1 ч добавляют 20 г хитозана. Смесь перемешивают в течение 4-5 ч до полного растворения хитозана. 
2. Гранулы из хитозана и термообработанной шелухи проса (ГХШП). Для этого в вышеописанную смесь хитозана с уксусной кислотой добавляют порошок измельченной термообработанной шелухи проса в количестве $20 \%$. Полученную смесь перемешивают до однородного состояния.

Смесь первого и второго видов вливают через шприцы в $5 \%$-й раствор едкого натрия (NaOH) (рис. 2). Сформированные гранулы выдерживают в течение суток в растворе щелочи $\mathrm{NaOH}$, с последующей промывкой водой до значений $\mathrm{pH} 7,0-7,5$ и высушивают при комнатной температуре в течение суток. Вид гранул представлен на рис. 3.

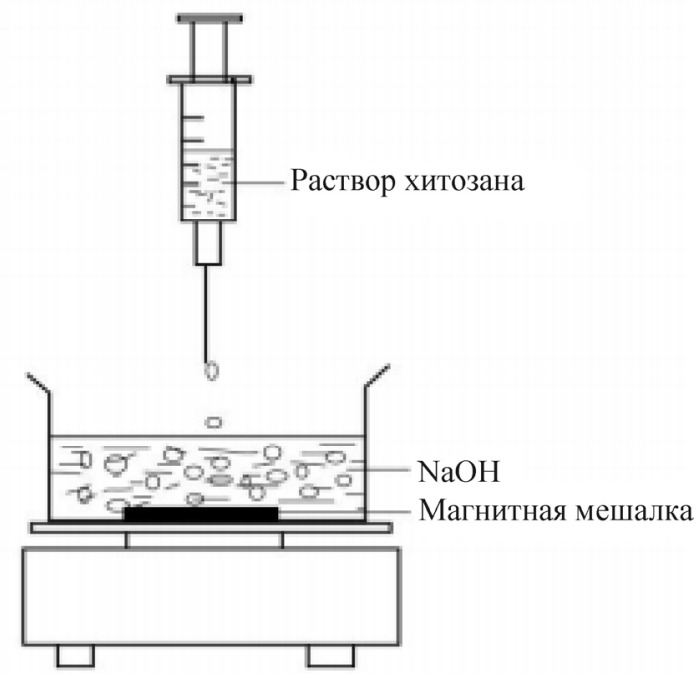

Рис. 2. Методика получения гранул (ГХ и ГХШП)

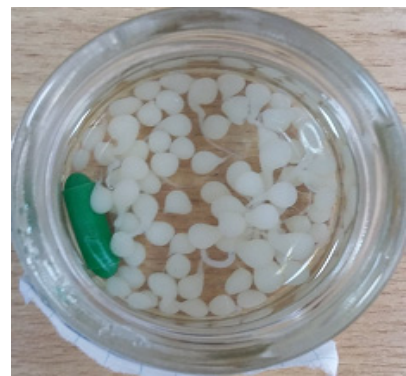

$a$

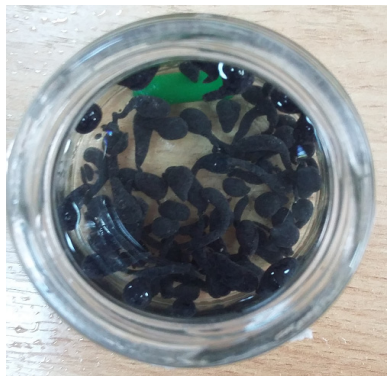

6

Рис. 3. Свежеприготовленные в растворе $5 \% \mathrm{NaOH}: a-$ гранулы

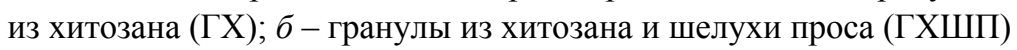


Полученные гранулы исследовали на способность извлекать ионы тяжелых металлов из модельных стоков. Модельные растворы, содержащие смесь ионов тяжелых металлов (ИТМ): $\mathrm{Pb}^{2+}, \mathrm{Cd}^{2+}$, $\mathrm{Zn}^{2+}$, изготавливали по ГОСТ 4212-76 «Методы приготовления растворов для колориметрического анализа». Раствор кадмия готовили из соли кадмия уксуснокислого. Навеску соли $2,370 \pm 0,003$ г растворяли в воде, которая содержала $0,5 \mathrm{~cm}^{3}$ кислоты и доводили до 1 л. Модельный раствор, содержащий ионы $\mathrm{Zn}^{2+}$, готовили из навески гранулированного цинка: 1 г растворяли в 7 см $^{3}$ раствора соляной кислоты (1:1) и доводили до 1 л водой. Модельный раствор готовили методом разбавления основного раствора раствором соляной кислоты, концентрация которого 0,001 н. Для приготовления раствора, содержащего ионы свинца (1 г/л), использовали навеску азотнокислого свинца. Навеску массой 1,6 г растворяли в воде в присутствии $1 \mathrm{~cm}^{3}$ азотной кислоты и доводили до 1 л. Из полученного раствора готовили растворы необходимых для эксперимента концентраций и далее разбавляли раствором азотной кислоты $(C=0,001$ н).

В приготовленные модельные растворы объемом 1 л добавляли по 20 г ГХ и ГХШП (см. рис. 3) и проводили процесс сорбции в статических условиях в течение 20 мин (время достижения сорбционного равновесия) [11] при постоянном перемешивании и термостатировании в интервале температур $293 \pm 2$ К. Для сравнения проводили аналогичный процесс сорбции с исходным хитозаном. После очистки стоков сорбент отделяли фильтрованием и определяли конечную концентрацию ионов тяжелых металлов вольтамперометрическим методом на приборе «Экотест-ВА» .

По конечным и начальным концентрациям определяли эффективность (Э) очистки стоков:

$$
\ni=\frac{C_{\text {нач }}-C_{\text {кон }}}{C_{\text {нач }}} \cdot 100 \%,
$$

где $C_{\text {нач }}$ и $C_{\text {кон }}$ - начальная и конечная концентрации раствора, $\mathrm{мг/л.}$

Рассчитанные значения эффективности очистки стоков от ИТМ представлены на рис. 4. 


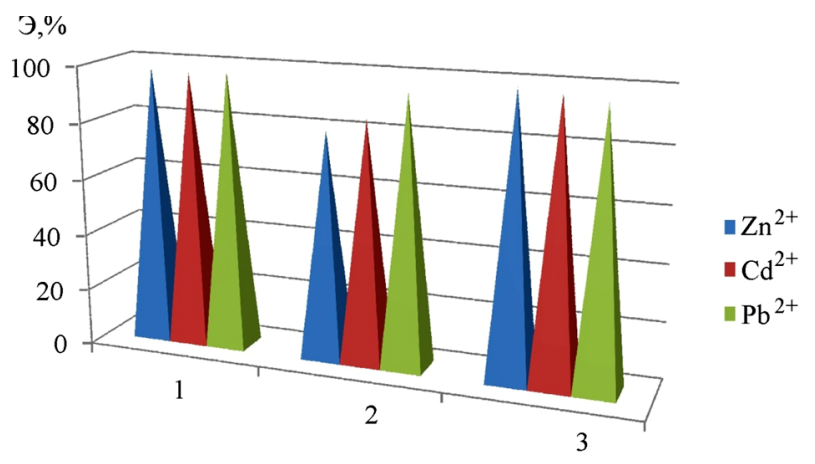

Рис. 4. Зависимость эффективности очистки сточных вод от ИТМ $\left(\mathrm{Pb}^{2+}, \mathrm{Cd}^{2+}, \mathrm{Zn}^{2+}\right)$ различными материалами: $1-\Gamma \mathrm{X}$;

2 - хитозан; 3 - ГХШП

При сравнении полученных результатов видно, что наиболее высокой эффективностью очистки обладает гранулированный сорбент по сравнению с исходным хитозаном. Эффективность очистки стоков с применением ГХ и ГХШП одинаково высокая (до 98 \%), но ГХШП позволяют утилизировать отходы сельхозпереработки.

На исходном и гранулированном хитозане снимали ИК-спектры (рис. 5) до и после очистки модельных растворов от ИТМ. При их изучении ИК-спектров были обнаружены полосы поглощения, характерные для валентных колебаний различных функциональных групп.

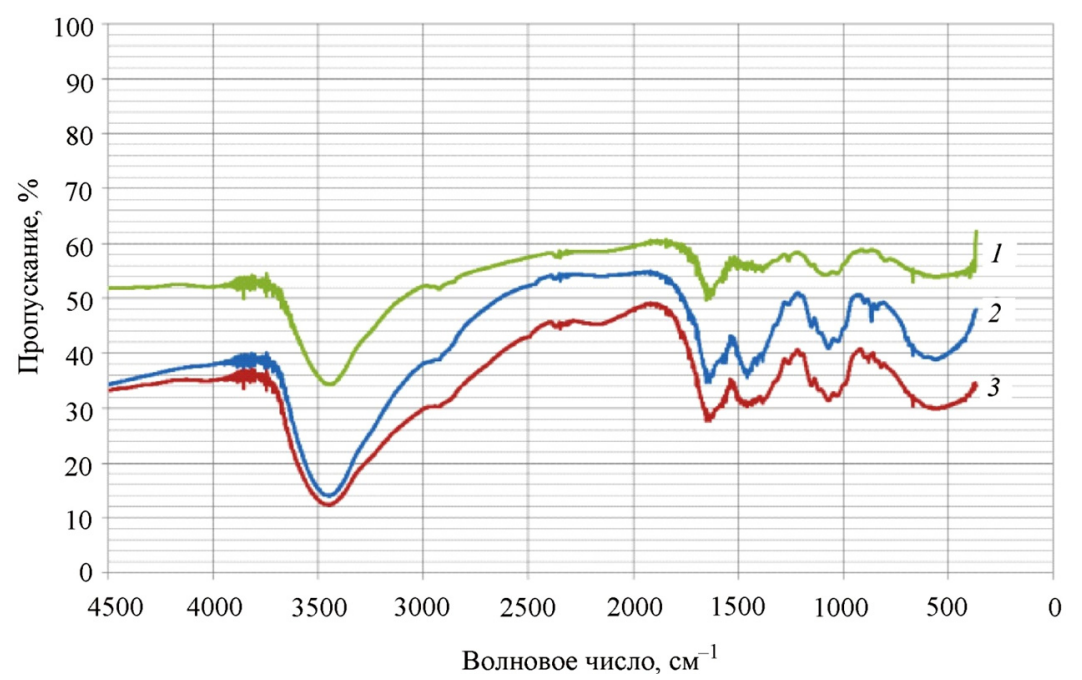

Рис. 5. ИК-спектры сорбентов из хитозана: 1 - гранулы после очистки стоков от ИТМ; 2 - гранулы до очистки; 3 - исходный хитозан 
На всех спектрах исходного сорбционного материала присутствуют пики при $3400 \mathrm{~cm}^{-1}$, характерные для валентных колебаний функциональной группы $\mathrm{O}-\mathrm{H}_{\text {вал }}$ - полосы поглощения гидроксильных групп, связанных водородными связями. В ИК-спектрах на сорбентах после очистки от ИТМ интенсивность поглощения, характерная для данной функциональной группы, уменьшена, следовательно, можно предположить, что при очистке ионов тяжелых металлов возможно протекание катионного обмена по схеме:

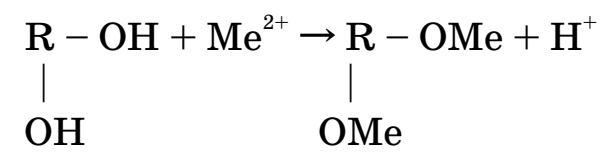

На графиках также выделяются пики, соответствующие диапазону 2310-2130 $\mathrm{cm}^{-1}$, характерные для соединения $\mathrm{N}^{+} \equiv \mathrm{N}_{\text {вал }}$. Пик в диапазоне 1260-970 см$^{-1}$ соответствует группе $\mathrm{C}-\mathrm{O}_{\text {вал }}^{\circ}$. Выделяется соединение $\mathrm{C}=\mathrm{O}_{\text {вал, }}$ находящееся в пределах 1765$1645 \mathrm{~cm}^{-1}$, что свидетельствует о возможности протекания хемосорбции, т.е. извлечение катионов тяжелых металлов из водных сред с протеканием химической реакции по схеме $\mathrm{R}=\mathrm{C}=\mathrm{O}+\mathrm{Me}^{+} \rightarrow \mathrm{R} \equiv \mathrm{C}-\mathrm{O}-\mathrm{Me}$.

При рассмотрении ИК-спектров всех модификаций видно, что пики находятся в одинаковых диапазонах, различаются только интенсивностью, следовательно, реакции протекают идентичные, но с разной эффективностью.

Следовательно, извлечение ИТМ сорбентами на основе хитозана происходит за счет катионного обмена и хемосорбционных процессов.

Микроструктурные исследования гранул на основе хитозана и термообработанной шелухи проса показали наличие более рыхлой структуры гранул на основе хитозана и термообработанной шелухи проса. На рис. 6, б видны поры и дефекты структуры, которые обусловливают физическую адсорбцию поллютантов из стоков.

Полученные материалы имеют различную себестоимость. Стоимость 1 кг хитозана составляет 2 тыс. руб. Произведем расчет себестоимости 1 кг гранулированного хитозана, который способен очистить около 50 л загрязненной воды. Материальные затраты 
на 1 кг гранул составят затраты на исходное сырье для изготовления сорбента (таблица).

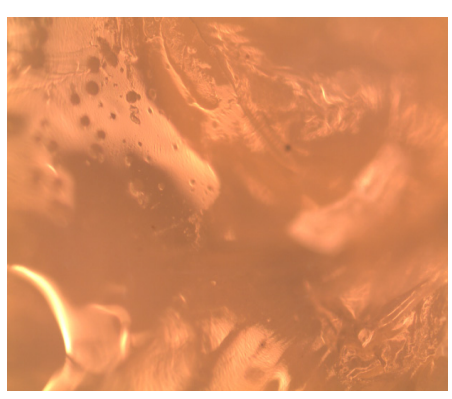

$a$

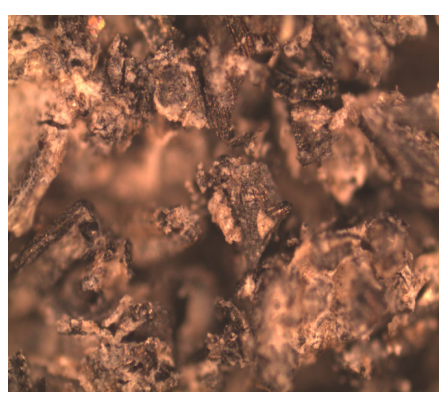

$\sigma$

Рис. 6. Микрофотография поверхности гранул: $a$ - на основе хитозана;

$\sigma$ - на основе хитозана и термообработанной шелухи проса $(\times 400)$

Стоимость расходных веществ

\begin{tabular}{|c|c|c|c|}
\hline Наименование & $\begin{array}{l}\text { Необходимое } \\
\text { кол-во }\end{array}$ & $\begin{array}{c}\text { Цена, руб. за } \\
\text { ед. продукции }\end{array}$ & $\begin{array}{l}\text { Общая стои- } \\
\text { мость, руб. }\end{array}$ \\
\hline \multicolumn{4}{|c|}{ Грануль из хитозана } \\
\hline Хитозан, кг & 0,02 & 2000 & 40 \\
\hline Гидроксид натрия, кг & 0,05 & 200 & 10 \\
\hline Уксусная кислота ледяная, л & 0,0328 & 100 & 3,2 \\
\hline Дистиллированная вода, л & 2,0 & 1,30 & 2,6 \\
\hline Итого за 1 кг латериала & & & 55,8 \\
\hline \multicolumn{4}{|c|}{ Гранулы из хитозана и терлообработанной шелухи проса } \\
\hline $\begin{array}{l}\text { Термообработанная шелуха } \\
\text { проса, кг }\end{array}$ & 0,2 & 20 & 4 \\
\hline $\begin{array}{l}\text { Раствор хитозана в уксусной } \\
\text { кислоте } 2 \%, \kappa \Gamma\end{array}$ & 0,8 & 43,20 & 34,5 \\
\hline Гидроксид натрия, л & 0,05 & 200 & 10 \\
\hline Уксусная кислота ледяная, л & 0,0328 & 100 & 3,2 \\
\hline Дистиллированная вода, л & 2,0 & 1,30 & 2,6 \\
\hline Итого за 1 кг латериала & & & 54,3 \\
\hline \multicolumn{4}{|c|}{ Хитозан } \\
\hline Итого за 1 кг материала & & & 2000 \\
\hline
\end{tabular}

Bъцводы:

1. В результате проделанной работы были изучены области применения хитозана, основными из которых является медицина и очистка стоков. 
2. Разработана технология получения гранулированных сорбционных материалов на основе хитозана и шелухи проса.

3. Показано, что наиболее высокой эффективностью очистки стоков от ионов тяжелых металлов обладают гранулированные сорбенты ГХ и ГХШП (до 98 \% ) по сравнению с исходным хитозаном.

4. Проведенная ИК-спектроскопия показала наличие функциональных групп $\mathrm{O}-\mathrm{H}_{\text {вал }} ; \mathrm{C}-\mathrm{O}_{\text {вал }}^{\circ} ; \mathrm{C}=\mathrm{O}_{\text {вал, }}$, которые позволили предположить хемосорбционный и катионообменный механизм извлечения ИТМ.

5. Рассчитанная себестоимость составила для ГХ 55,8 руб. за 1 кг, для ГХШП - 54,3 руб. за 1 кг, что доказывает экономическую целесообразность использования ГХ и ГХШП в качестве сорбционных материалов по сравнению с исходным хитозаном, себестоимость которого оставляет 2 тыс. руб. за 1 кг.

\section{Библиографический список}

1. Хитин и хитозан. Получение, свойства и применение / под ред. К.Г. Скрябина, Г.А. Вихоревой, В.П. Варламова. - М.: Наука, 2002. - 368 с.

2. Гальбрайх Л.С. Хитин и хитозан: строение, свойства, применение // Соровский образовательный журнал. - 2001. - Т. 7, № 1. - С. 51-56.

3. Горовой Л.Ф., Косяков В.Н. Сорбционные свойства хитина и его производных. - М.: Наука, 2002. - С. 217-246.

4. Сафронова Т.М. Применение хитозана в производстве пищевых продуктов // Хитин и хитозан. Получение, свойства, применение. - М.: Наука, 2002. - С. 346-359.

5. Дубинская А.М., Добротворский А.Е. Применение хитина и его производных в фармации (обзор) // Химико-фармацевтический журнал. - 1989. - Т. 23, № 5. C. 623-628.

6. Применение хитозана в лечебной косметике / В.М. Быкова, Л.И. Кривошеина, О.И. Глазунов, Е.А. Ежова // Новые достижения в исследовании хитина и хитозана: материалы VII междунар. конф. - М., 2003. - С. 231-233.

7. Быкова В.М., Ежова Е.А., Немцев С.В. Некоторые аспекты использования хитина и хитозана в качестве флокулянтов // Аграрная Россия. - 2004. - № 5. C. $30-31$.

8. Gil G., Del Monaco S., Galvagno M. Selective antimicrobial activity of chitosan on beer spoilage bacteria and brewing yeasts // Biotechnology letters. - 2004. - Vol. 26. P. 576-574.

9. Абдулин В.Ф., Артеменко С.Е., Арзамасцев О.С. Особенности процессов экстрагирования при извлечении биополимера хитина из панциря ракообразных // Химические волокна. - 2008. - № 6. - С. 21-24. 
10. Арзамасцев О.С., Артеменко С.Е., Абдуллин В.Ф. Интенсификация процесса получения пленок хитозана // Вестник Саратовского государственного технического университета. - 2011. - № 4 (60). - Вып. 2. - С.112-114.

11. Применение хитозана для удаления поллютантов из модельных стоков / Н.А. Собгайда, В.Ф. Абдуллин, Н.А. Влазнева, Д.А. Лавренов, К.И. Шайхиева // Вестник Казанского технологического университета. - 2014. - Т. 17, № 14. - С. 397 400.

12. Очистка сточных вод от ионов тяжелых металлов термообработанными отходами / Н.А. Собгайда, Л.Н. Ольшанская, Ю.А. Макарова, Н.Е. Попова // Экологические проблемы промышленных городов: сб. науч. тр. - Ч. 1. - Саратов: Изд-во Сарат. гос. техн. ун-та, 2009. - С. 321-324.

13. Собгайда Н.А., Ольшанская Л.Н., Макарова Ю.А. Влияние модифицирования шелухи пшеницы на ее сорбционные свойства к ионам $\mathrm{Pb}^{2+}, \mathrm{Cd}^{2+}, \mathrm{Zn}^{2+}$ и $\mathrm{Cu}^{2+} / /$ Изв. вузов. Химия и химическая технология. - 2010. - № 11. - С. 31-35.

\section{References}

1. Khitin and khitosan. Poluchenie, svojstva i prumenenie [Chitin and chitosan. Preparation, properties and applications]. Ed. by K.G. Scryabin, G.A. Vikhoreva, V.P. Varlamov. Moscow: Nauka, 2002. 368 p.

2. Galbraikh L.S. Khitin and khitosan: stroenie, svojstva i prumenenie [Chitin and Chitosan: structure, properties, application]. Sorovskij obrazovatelnyj zhurnal, 2001, vol. 7, no. 1, pp. 51-56.

3. Gorovoj L.F., Kosyakov V.N. Sorbtsionnye svojstva khitina i ego proizvodnykh [The sorption properties of chitin and its derivatives]. Moscow: Nauka, 2002. P. 217-246.

4. Safronov T.M. Primenenie khitozana v proizvodstve pishchevykh produktov [The use of chitosan in food production]. Moscow: Nauka, 2002. P. 346-359.

5. Dubinskaya A.M., Dobrotvorskij A.E. Primenenie khitina i ego proizvodnykh v farmatsii (obzor) [Application of chitin and its derivatives in pharmacy (review)]. Khimikofarmatsevticheskij zhurnal, 1989, vol. 23, no. 5, pp. 623-628.

6. Bykov V.M., Krivoshein L.I., Glazunov O.I., Yezhov E.A. Primenenie khitozana $\mathrm{v}$ lechebnoj kosmetike [The application of chitosan in medical cosmetics]. Materialy VII mezhdunarodnoj konferentsii «Novye dostizheniya $v$ issledovanii khitina $i$ khitozana». Moscow, 2003, pp. 231-233.

7. Bykov V.M., Yezhov E.A., Germans S.V. Primenenie khitozana v lechebnoj rosmetike [Some aspects of the use of chitin and chitosan as a flocculant]. Agrarnaya Rossiya, 2004, no. 5, pp. 30-31.

8. Gil G., Del Monaco S., Galvagno M. Selective antimicrobial activity of chitosan on beer spoilage bacteria and brewing yeasts. Biotechnology letters, 2004, vol. 26, pp. 576574.

9. Abdulin V.F., Artemenko S.E., Arzamasians O.S. Osobennosti protsessov ekstragirovaniya pri izvlechenii biopolimera khitina iz pantsyrej rakoobraznykh [Features of the extraction process the extraction of the biopolymer chitin crustaceans]. Khimicheskie volokna, 2008, no. 6, pp. 21-24. 
10. Arzamastsev O.S., Artemenko S.E., Abdullin V.F. Intensifikatsiya protsessa polucheniya plenok khitozana [The intensification of the process of producing films of chitosan]. Vestnik Saratovskogo gosudarstvennogo tekhnicheskogo universiteta, 2011, no. 4 (60), vol. 2, pp. 112-114.

11. Sobgajda N.A., Abdullin V.F., Vlazneva N.A, Lavrenov D.A., Shajkhieva K.I. Primenenie khitozana dlya udaleniya pollyutantov iz modelnykh stokov [Use of chitosan for removing pollutants from the runoff model]. Vestnik Kazanskogo tekhnicheskogo universiteta, 2014, vol. 17, no. 14, pp. 397-400.

12. Sobgajda N.A., Ol'shanskaya L.N., Makarova Y.A., Popova N.E. Ochistka stochnykh vod ot ionov tyazhelykh metallov termoobrabotannymi otkhodami [Wastewater treatment from heavy metal ions waste heat treated]. Ekologicheskie problemy promyshlennykh otkhodov. Saratov, 2009, pp. 321-324.

13. Sobgajda N.A., Ol'shanskaya L.N., Makarova Y.A. Vliyanie modifitsirovanoj shelukhi pshenitsy na ee sorbtsionnye svojstva $\mathrm{k}$ ionam $\mathrm{Pb}^{2+}, \mathrm{Cd}^{2+}, \mathrm{Zn}^{2+} \mathrm{i} \mathrm{Cu}^{2+}$ [Effect of modifying the husks of wheat on its sorption properties of ions $\mathrm{Pb}^{2+}, \mathrm{Cd}^{2+}, \mathrm{Zn}^{2+}$ и $\left.\mathrm{Cu}^{2+}\right]$. Izvestiya vuzov. Khimiya i khimicheskaya tekhnologiya, 2010, no. 11, pp. 31-35.

Получено 25.01.16

\author{
E. Taranovskaya, N. Sobgajda, D. Markina, P. Morev
}

\author{
PRODUCTION TECHNOLOGY AND USE \\ OF COMPOSITE MATERIALS OF CHITOSAN AND HUSK \\ APPLIED FOR WASTEWATER TREATMENT \\ FROM HEAVY METAL IONS
}

\begin{abstract}
The article describes main applications of the biopolymer - chitosan. The most important of them are found in medical industry where it is used as a means of combating obesity, binding and excreting cholesterol, preventing and treating cardiovascular diseases, treating cancer and stomach ulcers, and others; in food industry it is used as a thickener and formation structure of diet food. In recent years, many studies have been devoted to the application of chitosan. It is known that it has flocculation and sorption properties. Chitosan is expensive, so the paper prompts to create certain composite materials based on chitosan, which will reduce the cost and improve the sorption properties. As filler, it is proposed to use heat-treated millet husk, which has high sorption properties and, actually, it is a waste from processing agricultural products. The technology of obtaining and using composite materials from the husk of millet and chitosan for wastewater treatment from heavy metal ions $(\mathrm{Pb} 2+, \mathrm{Cd} 2+, \mathrm{Zn} 2+)$ has been developed. The authors calculated the efficiency of wastewater treatment using the original chitosan and composite granular materials based on chitosan and thermally treated mil-
\end{abstract}


let husks. It is shown that the composites based on chitosan and thermally treated millet hulls have a higher removal efficiency compared to the initial chitosan. Microstructural studies are conducted and the IR spectra of obtained materials are filmed. Economic indicators are calculated for production of composite materials.

Keywords: chitosan, heavy metal ions, millet husks, sewage.

Тарановская Елена Александровна (Энгельс, Россия) - соискатель кафедры «Экология и дизайн» Энгельсского технологического института Саратовского государственного технического университета ил. Ю.А. Гагарина (413100, г.Энгельс, пл.Свободы, 17, e-mail: Conata07@list.ru).

Собгайда Наталья Анатольевна (Энгельс, Россия) - д-р техн. наук, профессор кафедры «Экология и дизайн» Энгельсского технологического института Саратовского государственного технического университета ил. Ю.А. Гагарина (413100, г. Энгельс, пл. Свободы, 17, е-таil: Conata07@list.ru).

Маркина Диана Вадимовна (Энгельс, Россия) - студентка 4-го курса направления ТХНБ кафедры «Экология и дизайн» Энгельсского технологического института Саратовского государственного технического университета ил. Ю.А. Гагарина (413100, г. Энгельс, пл. Свободы, 17, e-mail:Conata07@list.ru).

Морев Павел Владимирович (Энгельс, Россия) - студент 3-го курса направления ТХНБ кафедры «Экология и дизайн» Энгельсского технологического института Саратовского государственного технического университета ил. Ю.А. Гагарина (413100, г. Энгельс, пл. Свободы, 17, e-mail:Conata07@list.ru).

Taranovskaya Elena (Engels, Russian Federation) - Competitor of the Department “Ecology and Design”, Engels Technological Institute of Saratov State Technical University named after Yuri Gagarin (413100, Engels, Sq. Svoboda,17,e-mail:Conata07@list.ru).

Sobgajda Nataliya (Engels, Russian Federation) - Professor of "Ecology and Design”, Engels Technological Institute of Saratov State Technical University named after Yuri Gagarin (413100, Engels, Sq. Svoboda, 17, e-mail: Conata07@list.ru).

Markina Diana (Engels, Russian Federation) - Student, Engels Technological Institute of Saratov State Technical University named after Yuri Gagarin (413100,Engels, Sq.Svoboda,17,e-mail:Conata07@list.ru).

Morev Pavel (Engels, Russian Federation) - Student, Engels Technological Institute of Saratov State Technical University named after Yuri Gagarin (413100, Engels, Sq.Svoboda, 17,e-mail:Conata07@list.ru). 